\title{
Low Density Lipoprotein Enhances the Cellular Action of Arginine Vasopressin in Rat Glomerular Mesangial Cells in Culture
}

\author{
San-e Ishikawa, Midori Kawasumi, Koji Okada, and Toshikazu Saito \\ Division of Endocrinology and Metabolism, Department of Medicine, Jichi Medical School, Tochigi 329-04 Japan
}

\begin{abstract}
The present study was undertaken to determine whether low density lipoprotein (LDL) modulates the cellular action of arginine vasopressin (AVP) in rat glomerular mesangial cells in culture. AVP increased cellular free calcium $\left(\left[\mathrm{Ca}^{2+}\right] \mathbf{i}\right)$ in a dose-dependent manner. When cells were preincubated for $24 \mathrm{~h}$ with $10 \mu \mathrm{g} / \mathrm{ml} \mathrm{LDL}$, the $1 \times 10^{-7} \mathrm{M}$ AVP-mobilized $\left[\mathrm{Ca}^{2+}\right] \mathrm{i}$ was $874 \mathrm{nM}$, a value significantly greater than that of $375 \mathrm{nM}$ in the intact cells. AVP caused a biphasic change in cellular $\mathbf{p H}$ (pHi), namely, an early acidification followed by a sustained alkalinization, and the change in pHi produced by AVP was also enhanced by LDL. AVP stimulated a 2.2-fold increase in $\left[{ }^{3} \mathrm{H}\right]$ thymidine incorporation, an effect significantly greater in the presence of $10 \mu \mathrm{g} / \mathrm{ml}$ LDL. Furthermore, $1 \times 10^{-7} \mathrm{MAVP}$ significantly activated mitogen-activated protein kinase from 14.0 to $24.5 \mathrm{pmol} / \mathrm{mg}$ protein. Such an activation was significantly enhanced by the LDL pretreatment. Both $\left[{ }^{3} \mathbf{H}\right]$ thymidine incorporation and mitogen-activated protein kinase were not altered by $10 \mu \mathrm{g} / \mathrm{ml} \mathrm{LDL}$. [ $\left.{ }^{3} \mathrm{H}\right] \mathrm{AVP}$ receptor binding was not affected by the LDL pretreatment. $1 \times 10^{-7} \mathrm{M} A$ VP increased inositol trisphosphate production by 1.9-fold, an effect significantly greater in the presence of LDL. These results indicate that LDL enhances the cellular action of AVP and the AVP-stimulated cellular proliferation in glomerular mesangial cells. A site of action of LDL is the hydrolysis of phosphatidylinositol. (J. Clin. Invest. 1994. 93:2710-2717.) Key words: low density lipoprotein • arginine vasopressin • signal transduction • cell growth • glomerular mesangial cells
\end{abstract}

\section{Introduction}

Arginine vasopressin (AVP) ${ }^{1}$ initiates a series of phosphatidylinositol breakdown that results in the accumulation of inositol

This study was presented at the 26th Annual Meeting of the American Society of Nephrology, November 1993, Boston, MA (1993. J. Am. Soc. Nephrol. 4:440).

Address correspondence to Dr. San-e Ishikawa, Division of Endocrinology and Metabolism, Department of Medicine, Jichi Medical School, 3311-1 Yakushiji Minamikawachi-machi, Tochigi 329-04, Japan.

Received for publication 11 October 1993 and in revised form 24 January 1994.

1. Abbreviations used in this paper: AVP, arginine vasopressin; BCECF-AM, 2',7'-bis-(2-carboxymethyl)5 (and 6) carboxyfluorescein acetoxymethyl ester; $\mathrm{IP}_{2}$ and $\mathrm{IP}_{3}$, insitol bisphosphate and insitol trisphosphate, respectively; MAP, mitogen-activated protein; PSS, physiological saline solution; SBFI/AM, sodium-binding benzofuran isophthalate acetoxymethyl ester.

J. Clin. Invest.

(c) The American Society for Clinical Investigation, Inc.

0021-9738/94/06/2710/08 \$2.00

Volume 93, June 1994, 2710-2717 1,4,5-trisphosphate $\left(\mathrm{IP}_{3}\right)$ and diacylglycerol, leading to mobilization of cellular free calcium ( $\left.\left[\mathrm{Ca}^{2+}\right] \mathrm{i}\right)$ from endoplasmic reticulum and the stimulation of protein kinase $\mathrm{C}$ in glomerular mesangial cells (1-4). AVP also produces a biphasic change in cellular $\mathrm{pH}(\mathrm{pHi})$, i.e., a transient acidification followed by a sustained alkalinization (5). We demonstrated that AVP increases cellular sodium concentration controlled by $\left[\mathrm{Ca}^{2+}\right] \mathrm{i}$ in glomerular mesangial cells (6). Cellular alkalinization is dependent on $\mathrm{Na}^{+}$entry in exchange for $\mathrm{H}^{+}$secretion, which is closely related to cell contraction and proliferation of mesangium $(2,5)$. Similar results were obtained in homologous cells of vascular smooth muscle (7-10). Recently, it is also demonstrated that AVP acts as growth factor in normal and abnormal cell development (11). AVP induces c-fos protein and activates mitogen-activated protein (MAP) kinase in glomerular mesangial cells and vascular smooth muscle cells (11-15). MAP kinase plays a key role in the signal transduction through both protein kinases and protein phosphatases (16).

The frequency of atherosclerosis is increased in hypertension, and the risk is proportional to the severity of the antecedent hypertension. There is increasing evidence to suggest that, as in atherogenesis, abnormalities in lipoprotein metabolism may influence the pathogenesis of hypertensive disease (17). Plasma low density lipoprotein (LDL)-cholesterol concentrations are frequently increased in hypertension (18). Furthermore, hypertension-associated disturbance in lipid metabolism are aggravated by hyperinsulinemia (19), suggesting a complex interaction between lipoprotein metabolism and cardiovascular risk factors, including glomerulosclerotic disorder. The evidence indicates that not only the lipoprotein metabolism but also the ability of lipoproteins exert direct hormonal actions in vascular beds $(20,21)$. There were also LDL receptors and scavenger receptors in glomeruli $(22,23)$.

The present study was undertaken to determine whether LDL affects the cellular action of AVP in the cultured rat glomerular mesangial cells. Also, whether LDL modulates the cellular proliferative action of AVP to activate MAP kinase and thymidine incorporation was examined.

\section{Methods}

Cell culture. The experimental procedure was similar to that described in the previous study (6), modified from the method of Kreisberg and Karnovsky (24). Male Sprague-Dawley rats weighing 150-175 g were used. Kidneys were removed under sterile conditions, and cortical tissues were cut away from the medulla. They were minced with $1 \mathrm{ml}$ of physiological saline solution (PSS; $140 \mathrm{mM} \mathrm{NaCl}, 4.6 \mathrm{mM} \mathrm{KCl}, 1 \mathrm{mM}$ $\mathrm{MgCl}_{2}, 2 \mathrm{mM} \mathrm{CaCl}_{2}, 10 \mathrm{mM}$ glucose, and $10 \mathrm{mM}$ Hepes, pH 7.4) by a sharp razor blade. The minced renal cortical tissues were incubated with $3 \mathrm{ml}$ of collagenase $(1 \mathrm{mg} / \mathrm{ml}$; Worthington Biochemical Corp., Freehold, $\mathrm{NJ}$ ) for $60 \mathrm{~min}$ at $37^{\circ} \mathrm{C}$. They were passed through a series of steel sieves with decreasing pore sizes (60 and 200 mesh) with the glomeruli appearing on top of the 200 -mesh sieve. The glomeruli were collected into culture tubes, and were centrifuged at $500 \mathrm{~g}$ for $4 \mathrm{~min}$ at room temperature. After aspirating the supernatants, the pellets were resuspended with DME (Flow Laboratories, Inc., McLean, VA) supple- 
mented with $20 \%$ fetal bovine serum, $100 \mathrm{U} / \mathrm{ml}$ penicillin, and 100 $\mu \mathrm{g} / \mathrm{ml}$ streptomycin. The dispersed glomeruli were harvested into 35 $\times 10-\mathrm{mm}$ plastic dishes with the medium and kept in a humidified incubator at $37^{\circ} \mathrm{C}$ under $95 \%$ air and $5 \% \mathrm{CO}_{2}$.

After the cultured cells were confluent, they were subcultured using $\mathrm{Ca}^{2+}$-free and $\mathrm{Mg}^{2+}$-free Hank's solution containing $0.025 \%$ trypsin and $0.01 \%$ EDTA. The dispersed cells were collected into culture tubes and centrifuged at $500 \mathrm{~g}$ for $4 \mathrm{~min}$ at room temperature. The pellets were resuspended in DME containing 20\% fetal bovine serum, penicillin, and streptomycin and cultured in a humidified incubator. The cultured cells at the 3 rd through 10 th passages were subjected to the following studies on days $7-10$ of the subculture.

For measurements of $\left[\mathrm{Ca}^{2+}\right] \mathrm{i}, \mathrm{pHi}$, and $\left[\mathrm{Na}^{+}\right] \mathrm{i}$, the cells were cultured on thin glass slides ( $13 \mathrm{~mm}$ in diameter; Matsunami Kogyo Co., Osaka ). The cultured cells were grown in $35 \times 10-\mathrm{mm}$ plastic dishes to study AVP receptor binding, MAP kinase activity, and $\mathrm{IP}_{3}$ production. Also, they were grown in 24-well tissue culture clusters (Costar, Cambridge, MA) to measure thymidine incorporation.

Measurement of $\left[\mathrm{Ca}^{2+}\right] i$. The experimental procedure was similar to that used in our previous studies $(25,26)$. The cells were preincubated with the medium containing human LDL (Biomedical Technologies, Stoughton, MA) for the indicated times and then rinsed twice with $1 \mathrm{ml}$ PSS. They were loaded with $5 \mu \mathrm{M}$ fura-2/AM (Dojin Biochemicals, Kumamoto) for $60 \mathrm{~min}$ at $37^{\circ} \mathrm{C}$ in a volume of $250 \mu \mathrm{l}$ PSS containing LDL. Control group of cells were performed with the vehicle in a same manner. Similarly, the study was performed with $10 \mu \mathrm{g} / \mathrm{ml}$ of the oxidized LDL. The oxidized LDL was prepared by incubating 200 $\mu \mathrm{g} / \mathrm{ml} \mathrm{LDL}$ in PSS containing $5 \mu \mathrm{M} \mathrm{CuSO}_{4}$ for $24 \mathrm{~h}$ (27). After aspiration of the fura-2/AM solution, the glass slides were rinsed and then placed in a $1 \times 1-\mathrm{cm}$ quartz cuvette with the aid of a special holder in a fluorescence spectrophotometer (CAF-110, Japan Spectroscopic Co., Tokyo). The dual-wavelength excitation method for measurement of fura-2 fluorescence was used. The fluorescence was monitored at 500 $\mathrm{nm}$, with excitation wavelengths of 340 and $380 \mathrm{~nm}$ in the ratio mode. The effector of AVP (Sigma Chemical Co., St. Louis, MO) was added after a stable fluorescence signal $(R)$ was achieved. From the ratio of fluorescence at 340 and $380 \mathrm{~nm}$, the $\left[\mathrm{Ca}^{2+}\right] \mathrm{i}$ was determined as described by Grynkiewicz et al. (28), using the following expression: $\left[\mathrm{Ca}^{2+}\right] \mathrm{i}(\mathrm{nM})=K_{\mathrm{d}} \times\left[\left(R-R_{\min }\right) /\left(R_{\max }-R\right)\right] \times \beta$, where $R$ is the ratio of fluorescence of the sample at 340 and $380 \mathrm{~nm}$, and $R_{\max }$ and $R_{\min }$ were determined as described previously (25). The term $\beta$ is the ratio of fluorescence of fura-2 at $380 \mathrm{~nm}$ in zero and saturating $\mathrm{Ca}^{2+}$ concentrations. $K_{\mathrm{d}}$ is the dissociation constant of fura- 2 for $\mathrm{Ca}^{2+}$, assumed to be $224 \mathrm{nM}$ at $37^{\circ} \mathrm{C}(28)$.

Measurement of $\mathrm{pHi}$. The experimental procedure was similar to that reported in our previous studies $(29,30)$. The study was performed in $\mathrm{HCO}_{3}$-free buffer using PSS. The cells were preincubated with the medium containing $10 \mu \mathrm{g} / \mathrm{ml} \mathrm{LDL}$ for $24 \mathrm{~h}$ and then rinsed twice with $1 \mathrm{ml}$ of PSS. They were loaded with $2 \mu \mathrm{M}$ BCECF/AM (Molecular Probes, Inc., Eugene, OR) for $60 \mathrm{~min}$ at $37^{\circ} \mathrm{C}$ in a volume of $250 \mu \mathrm{l}$ of PSS containing $10 \mu \mathrm{g} / \mathrm{ml} \mathrm{LDL}$. The complete intracellular hydrolysis of 2',7'-bis-(2-carboxymethyl)5 (and 6) carboxyfluorescein acetoxymethyl ester (BCECF/AM) to BCECF was judged by changes in the excitation and emission spectra. The fluorescence was monitored at $500 \mathrm{~nm}$, with excitation wavelengths of 450 and $500 \mathrm{~nm}$ in the ratio mode. After measurement of the basal pHi level, AVP was added. The fluorescence signal was calibrated at several $\mathrm{pH}$ values $(6.6,7.0$, and 7.4 ) in the $\mathrm{KCl}$ solution ( $140 \mathrm{mM} \mathrm{KCl}, 4.6 \mathrm{mM} \mathrm{NaCl}, 1 \mathrm{mM} \mathrm{MgCl}$, $2 \mathrm{mM} \mathrm{CaCl}, 10 \mathrm{mM}$ glucose, and $10 \mathrm{mM}$ Hepes) containing the $\mathrm{K}^{+} / \mathrm{H}^{+}$ionophore nigericin $(10 \mu \mathrm{g} / \mathrm{ml})$.

Measurement of $\left[\mathrm{Na}^{+}\right] \mathrm{i}$. The experimental procedure was similar to that described previously $(6,29)$. The cells were preincubated with the medium containing $10 \mu \mathrm{g} / \mathrm{ml} \mathrm{LDL}$ for $24 \mathrm{~h}$ and then rinsed twice with $1 \mathrm{ml}$ of PSS. They were loaded with $10 \mu \mathrm{M} \mathrm{SBFI} / \mathrm{AM}$ (Molecular Probes, Inc.) for $3 \mathrm{~h}$ at $37^{\circ} \mathrm{C}$ in a volume of $250 \mu \mathrm{l}$ PSS containing 10 $\mu \mathrm{g} / \mathrm{ml} \mathrm{LDL}$. Sodium-binding benzofuran isophthalate acetoxymethyl ester (SBFI/AM) was dissolved in PSS containing $0.02 \%$ pluronic F-127, a nonionic detergent. After aspirating the SBFI/AM solution, the glass slides were rinsed and then placed in a $1 \times 1-\mathrm{cm}$ quartz cuvette with the aid of a special holder in a fluorescence spectrophotometer (CAF-100, Japan Spectroscopic Co.). The dual-wavelength excitation method for measurement of SBFI fluorescence was used. The fluorescence was monitored at $500 \mathrm{~nm}$, with excitation wavelengths of 340 and $380 \mathrm{~nm}$ in the ratio mode, in a manner similar to the monitoring of the effect of calcium on fura-2. After a stable fluorescence signal was achieved, AVP was added. $\left[\mathrm{Na}^{+}\right] \mathrm{i}$ was calibrated by equilibrating $\left[\mathrm{Na}^{+}\right] \mathrm{i}$ with the extracellular $\mathrm{Na}^{+}$concentration, using $1 \times 10^{-6} \mathrm{M}$ gramicidine. The reference standard solutions were made from appropriate mixtures of $\mathrm{Na}^{+}$and $\mathrm{K}^{+}$solutions, based on the solution of PSS. The total concentration of $\mathrm{Na}^{+}$and $\mathrm{K}^{+}$were adjusted to $135 \mathrm{mM}$. The $\left[\mathrm{Na}^{+}\right] \mathrm{i}$ was determined by the relation between the ratio and the authentic $\left[\mathrm{Na}^{+}\right] \mathrm{i}$.

Measurement of thymidine incorporation. Cells grown in 24-well tissue culture clusters were used to assess DNA replication. At confluency, the cells were synchronized to the quiescent state by incubation in $1 \mathrm{ml}$ of serum-free DME. After $48 \mathrm{~h}$, cells were exposed to the varying stimuli which were dissolved in the serum-free DME. The medium contained $\left[{ }^{3} \mathrm{H}\right.$ ] thymidine $(1 \mu \mathrm{Ci} /$ well; sp act $80.8 \mathrm{Ci} / \mathrm{mmol}$; New England Nuclear, Wilmington, DE). The stimuli included 1 $\times 10^{-7} \mathrm{M}$ AVP, and 1,10 , or $100 \mu \mathrm{g} / \mathrm{ml} \mathrm{LDL}$. Also, the study was carried out with $10 \mu \mathrm{g} / \mathrm{ml}$ of the oxidized LDL. The cells were incubated with $1 \mathrm{ml}$ of the effector for an additional $24 \mathrm{~h}$ in the humidified incubator. Thereafter, the cells were rinsed four times with PSS and immersed with $0.5 \mathrm{ml}$ of $0.1 \mathrm{~N} \mathrm{NaOH}$ containing 1\% SDS. They were collected into counting vials by Eppendorf chips and with $10 \mathrm{ml}$ of scintillation solution then added. The radioactivity was measured using a liquid scintillation counter (Aloka LSC-671, Tokyo). Cells grown on several wells of 24-well tissue culture cluster were collected in a same manner and protein contents were measured by the method of Lowry et al. (31).

MAP kinase assay. The experimental procedure was modified from the method of Shirakabe et al. (32). Cells grown on $35 \times 10-\mathrm{mm}$ plastic dishes were incubated with serum-free DME in the presence or absence of 10 or $100 \mu \mathrm{g} / \mathrm{ml}$ LDL $24 \mathrm{~h}$ before the start of the experiments. Also, the study was carried out with $10 \mu \mathrm{g} / \mathrm{ml}$ of the oxidized LDL. The cells were rinsed twice with $2 \mathrm{ml}$ of PSS. The cells were incubated for $10 \mathrm{~min}$ at $37^{\circ} \mathrm{C}$ with $1 \mathrm{ml}$ of $1 \times 10^{-7} \mathrm{M}$ AVP or $1 \times 10^{-6}$ M PMA (Sigma Chemical Co.). After aspiration of the effector solutions, the cells were exposed to $0.5 \mathrm{ml}$ of the solution containing 20 $\mathrm{mM}$ Tris, $5.6 \mathrm{mM} \beta$-glycerophosphate, $10 \mathrm{mM}$ EGTA, $10 \mathrm{mM} \mathrm{MgCl}_{2}$, $0.1 \mathrm{mM} \mathrm{NaF}, 2 \mathrm{mM}$ DTT, $1 \mathrm{mM} \mathrm{NaVO}, 20 \mu \mathrm{g} / \mathrm{ml}$ aprotinin, and 1 $\mathrm{mM}$ PMSF, $\mathrm{pH}$ 7.5. Thereafter, the dishes were immediately put on dry ice. The extracts were collected into microcentrifuge tubes by Eppendorf chips. After centrifugation, the supernatants were transferred to plastic tubes and kept at $-20^{\circ} \mathrm{C}$ until the time of assay.

Glass tubes containing $60 \mu \mathrm{l}$ of the assay mixture ( $40 \mathrm{mM}$ Tris, 40 $\mathrm{mM} \mathrm{MgCl}, 2.5 \mathrm{mg} / \mathrm{ml}$ myelin basic protein [Sigma Chemical Co.], $0.5 \mathrm{mM}$ ATP, and $0.5 \mu \mathrm{Ci}{ }^{32} \mathrm{P}-\gamma \mathrm{ATP}$ [sp act $>10 \mathrm{Ci} / \mathrm{mmol}$; Amersham, Int., Amersham, Buckinghamshire, UK]) were incubated at $25^{\circ} \mathrm{C}$ for $15 \mathrm{~min}$. Then $40 \mu \mathrm{l}$ of samples was added and the mixtures were incubated for an additional $10 \mathrm{~min}$ at $25^{\circ} \mathrm{C}$. The mixtures were transferred onto glass microfiber filters (Whatman 2.4-cm GF/C; Whatman, Maidstone, England) by using Eppendorf chips. The filters were then put into ice-cold $10 \%$ trichloroacetic acid containing $50 \mathrm{mM}$ sodium pyrophosphate, and shaken gently for $20 \mathrm{~min}$. This maneuver was repeated four times. The filters were immersed in ice-cold ethanol for $20 \mathrm{~min}$. After the filters were exposed to diethylether, they were put into counting vials containing $10 \mathrm{ml}$ of scintillation solution. The radioactivity was counted by using Aloka liquid scintillation counter. Also, cellular protein of all samples was measured by the method of Lowry et al. (31).

$A V P$ receptor binding. The experimental procedure was similar to that described previously (30), modified from the method of Fishman et al. (33). Cells were grown on $35 \times 10-\mathrm{mm}$ plastic dishes. Cells were exposed for $24 \mathrm{~h}$ to the medium containing $10 \mu \mathrm{g} / \mathrm{ml} \mathrm{LDL}$ or the vehicle before the start of experiments. They were rinsed twice with 2 
$\mathrm{ml}$ ice-cold binding buffer ( $119.2 \mathrm{mM} \mathrm{NaCl}, 3.0 \mathrm{mM} \mathrm{KCl}, 1.2 \mathrm{mM}$ $\mathrm{MgSO}_{4}, 1.0 \mathrm{mM} \mathrm{CaCl}_{2}, 1.2 \mathrm{mM} \mathrm{KH}_{2} \mathrm{PO}_{4}, 10 \mathrm{mM}$ glucose, and $25 \mathrm{mM}$ Hepes as well as $0.1 \% \mathrm{BSA}, \mathrm{pH} \mathrm{7.4)}$ and then incubated with $1 \mathrm{ml}$ ice-cold binding buffer containing $2 \times 10^{-9} \mathrm{M}\left[{ }^{3} \mathrm{H}\right.$ ]AVP (sp act 67.6 $\mathrm{Ci} / \mathrm{mmol}$; New England Nuclear) in the absence or presence of 1 $\times 10^{-6} \mathrm{M}$ AVP at $4^{\circ} \mathrm{C}$ for $60 \mathrm{~min}$. The buffer also contained $10 \mu \mathrm{g} / \mathrm{ml}$ LDL which was similar to that during the preincubation. Control group was carried out with the vehicle in a similar manner. After the incubation, the cells were rinsed four times with $2 \mathrm{ml}$ of ice-cold binding buffer, followed by the addition of $1 \mathrm{ml}$ SDS alkaline solution (1\% SDS and $0.1 \mathrm{~N} \mathrm{NaOH}$ ). The radioactivity was counted with a liquid scintillation counter. Protein was measured by the method of Lowry et al. (31).

Measurement of inositol trisphosphate. Cells grown on $35 \times 10$ $\mathrm{mm}$ plastic dishes were used in the present study. The measurement of the intracellular levels of $\mathrm{IP}_{3}$ were performed as described previously (34). The cells were washed twice with $2 \mathrm{ml}$ of inositol-free DME and incubated with $2 \mathrm{ml}$ of inositol-free DME containing $5 \mu \mathrm{Ci} / \mathrm{ml}$ [ myo${ }^{3} \mathrm{H}$ ] inositol ( $\mathrm{sp}$ act $19.1 \mathrm{Ci} / \mathrm{mmol}$, Amersham) for $24 \mathrm{~h}$ in a humidified incubator. The medium also contained $10 \mu \mathrm{g} / \mathrm{ml} \mathrm{LDL}$ or the vehicle. At the time of the experiment, the cells were rinsed twice with $2 \mathrm{ml}$ of PSS and then incubated with $0.8 \mathrm{ml}$ of PSS containing $1 \times 10^{-7} \mathrm{M}$ AVP for $10 \mathrm{~s}$. The reaction was stopped by the addition of $0.2 \mathrm{ml}$ of $50 \%$ trichloroacetic acid, and then the cells were scraped using Eppendorf pipette chips. The suspensions containing the disrupted cells were centrifuged using a microcentrifuger. The supernatants were washed five times with ether and the water-soluble fractions were brought to pH 7.0 using $1 \mathrm{~N} \mathrm{NaOH}$ and stored at $-20^{\circ} \mathrm{C}$ until the analysis. The pellets were dissolved with $1 \mathrm{ml} 0.1 \mathrm{~N} \mathrm{NaOH}$ containing $1 \%$ SDS and stored at $4^{\circ} \mathrm{C}$ for protein assay. The water-soluble fractions were applied to columns containing $1 \mathrm{ml}$ of Dowex ( $1-\times 8$, formate form, Muromachi Kagaku Kogyo, Tokyo) and serially eluted 10 times with 2-ml aliquots of $\mathrm{H}_{2} \mathrm{O}$, Borax ( $5 \mathrm{mM}$ disodium tetraborate, $60 \mathrm{mM}$ sodium formate), $0.2,0.4$, and $1.0 \mathrm{M}$ ammonium formate in $0.1 \mathrm{M}$ formic acid. This maneuver separated inositol, glycerophosphatidylinositol, inositol-1-phosphate, inositol bisphosphate $\left(\mathrm{IP}_{2}\right)$ and $\mathrm{IP}_{3}$, respectively. $\mathrm{IP}_{3}$ fractions includes $1,3,4-\mathrm{IP}_{3}, 1,4,5-\mathrm{IP}_{3}$, and 1,3,4,5-inositol tetrakisphosphate. Samples were collected into scintillation counter vials and counted using a liquid scintillation counter.

Statistics. All values of $\left[\mathrm{Ca}^{2+}\right] \mathrm{i}, \mathrm{pHi},\left[\mathrm{Na}^{+}\right] \mathrm{i},\left[{ }^{3} \mathrm{H}\right]$ thymidine incorporation, MAP kinase activity, and $\mathrm{IP}_{3}$ production were analyzed by an analysis of multiple variance and Student's $t$ test. $P<0.05$ was considered significant.

\section{Results}

Fig. 1 shows the effect of LDL on the AVP-mobilized $\left[\mathrm{Ca}^{2+}\right] \mathrm{i}$ in the cultured rat glomerular mesangial cells. AVP increased $\left[\mathrm{Ca}^{2+}\right] \mathrm{i}$ in a dose-dependent manner. $1 \times 10^{-7} \mathrm{M}$ AVP raised $\left[\mathrm{Ca}^{2+}\right]$ i from $94.2 \pm 7.1$ to $375.2 \pm 22.9 \mathrm{nM}(P<0.01)$. When cells were preincubated with $10 \mu \mathrm{g} / \mathrm{ml} \mathrm{LDL}$ for $24 \mathrm{~h}$, the AVPmobilized $\left[\mathrm{Ca}^{2+}\right] \mathrm{i}$ was markedly enhanced. Namely, the 1 $\times 10^{-7} \mathrm{M}$ AVP-induced increase in $\left[\mathrm{Ca}^{2+}\right] \mathrm{i}$ was $874.7 \pm 66.4$ $\mathrm{nM}$ in the cells pretreated with $10 \mu \mathrm{g} / \mathrm{ml} \mathrm{LDL}$, a value significantly greater than that of $375.2 \pm 22.9 \mathrm{nM}$ in the intact cells. Also, the LDL pretreatment enhanced the sustained elevation of $\left[\mathrm{Ca}^{2+}\right] \mathrm{i}$ induced by AVP (data not shown). The 24-h exposure of cells to $10 \mu \mathrm{g} / \mathrm{ml} \mathrm{LDL}$ did not affect the basal levels of $\left[\mathrm{Ca}^{2+}\right]$ i. Also, we studied the effect of the oxidized LDL on $\left[\mathrm{Ca}^{2+}\right] \mathrm{i}$ in the cultured rat glomerular mesangial cells. When cells were exposed to $10 \mu \mathrm{g} / \mathrm{ml}$ of the oxidized LDL for $24 \mathrm{~h}$, the $1 \times 10^{-7}$ M AVP-mobilized [ $\mathrm{Ca}^{2+}$ ] i was $410.5 \pm 40.9 \mathrm{nM}(n$ $=5)$, a value less than that in the cells preincubated with 10 $\mu \mathrm{g} / \mathrm{ml} \mathrm{LDL}(P<0.01)$. In addition, an acute effect of LDL on $\left[\mathrm{Ca}^{2+}\right] \mathrm{i}$ was not found, since there was no alteration in $\left[\mathrm{Ca}^{2+}\right] \mathrm{i}$ after exposing to $10 \mu \mathrm{g} / \mathrm{ml} \mathrm{LDL}$ (data not shown).

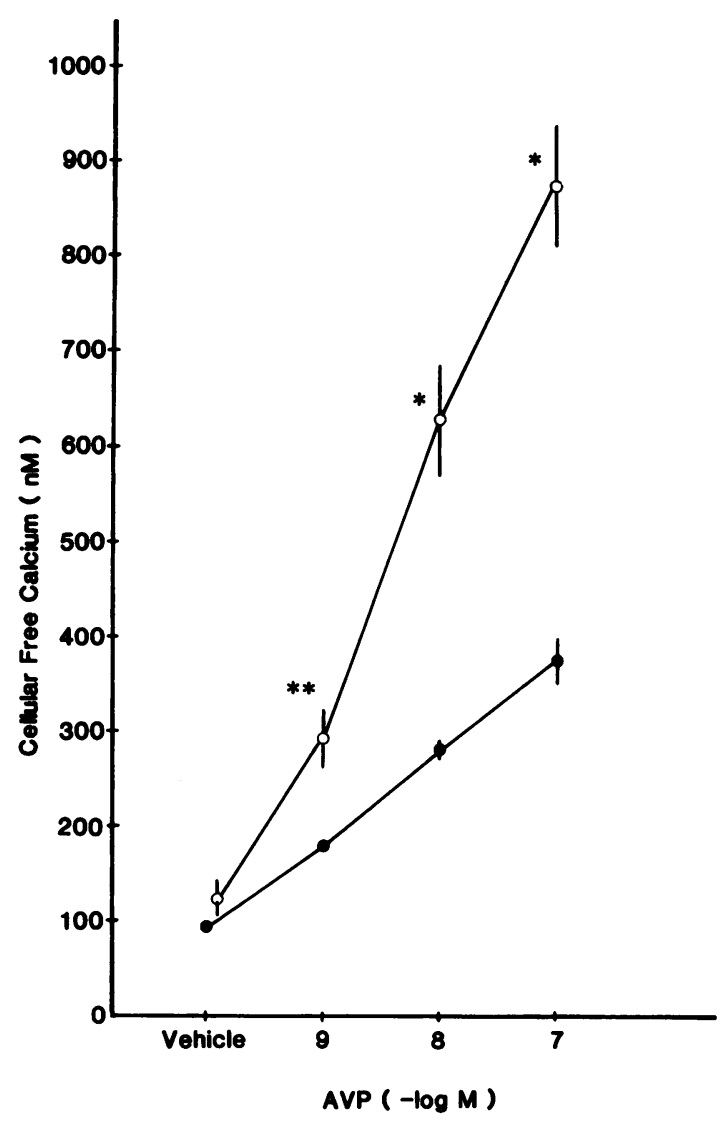

Figure 1. Effect of LDL on the AVP-induced increase in cellular free calcium in the cultured rat glomerular mesangial cells. (•) Control group. (O) LDL group of cells, which were preincubated for $24 \mathrm{~h}$ with $10 \mu \mathrm{g} / \mathrm{ml} \mathrm{LDL.}{ }^{*} P<0.01$ and ${ }^{* *} P<0.05$ vs. the control group. Values are means $\pm \mathrm{SEM}, n=5$.

Also, the enhancement by LDL of the AVP-mobilized $\left[\mathrm{Ca}^{2+}\right] \mathrm{i}$ is depicted in Fig. 2. When cells were preexposed to $\mathrm{LDL}$ for $24 \mathrm{~h}$, the greater response of $\left[\mathrm{Ca}^{2+}\right] \mathrm{i}$ to $1 \times 10^{-7} \mathrm{M}$ AVP was obtained with the higher concentration of LDL. In contrast, the basal level of $\left[\mathrm{Ca}^{2+}\right] \mathrm{i}$ remained unchanged in the absence and presence of LDL. As shown in Fig. 3, the enhancement by $10 \mu \mathrm{g} / \mathrm{ml} \mathrm{LDL}$ of the AVP-induced increase in $\left[\mathrm{Ca}^{2+}\right]$ $i$ was dependent on the preincubation with LDL. The augmentation appeared after the 3-h preincubation with LDL.

We also monitored the pHi change in response to AVP in the cultured rat glomerular mesangial cells (Fig. 4). After the exposure of cells to $1 \times 10^{-7} \mathrm{M}$ AVP, the initial acidification occurred during the 3-min observation period, followed by the sustained alkalinization. The basal pHi was $7.18 \pm 0.01$, and the minimal and maximal $\Delta \mathrm{pHi}$ were $-0.03 \pm 0.01$ and $0.07 \pm 0.01$, respectively. In the cells pretreated with $10 \mu \mathrm{g} / \mathrm{ml} \mathrm{LDL}$ for 24 $h$, the sustained alkalinization was significantly enhanced.

Effect of LDL on the AVP-induced increase in $\left[\mathrm{Na}^{+}\right] \mathrm{i}$ in the cultured rat glomerular mesangial cells is shown in Fig. 5. As described previously (6), AVP caused a sustained increase in $\left[\mathrm{Na}^{+}\right]$i. $1 \times 10^{-7} \mathrm{M}$ AVP rose [ $\left.\mathrm{Na}^{+}\right]$i to $17.6 \pm 0.7$ from $8.2 \pm 0.6 \mathrm{mM}(P<0.01)$. A 24-h exposure of cells to $10 \mu \mathrm{g} / \mathrm{ml}$ LDL significantly enhanced the AVP-induced increase in $\left[\mathrm{Na}^{+}\right]$i. LDL per se did not alter the basal level of $\left[\mathrm{Na}^{+}\right]$i.

Fig. 6 shows $\left[{ }^{3} \mathrm{H}\right]$ thymidine incorporation into quescent glomerular mesangial cells exposed to the serum-free DME to assess DNA replication. $1 \times 10^{-7} \mathrm{M}$ AVP stimulated a 2.2-fold 


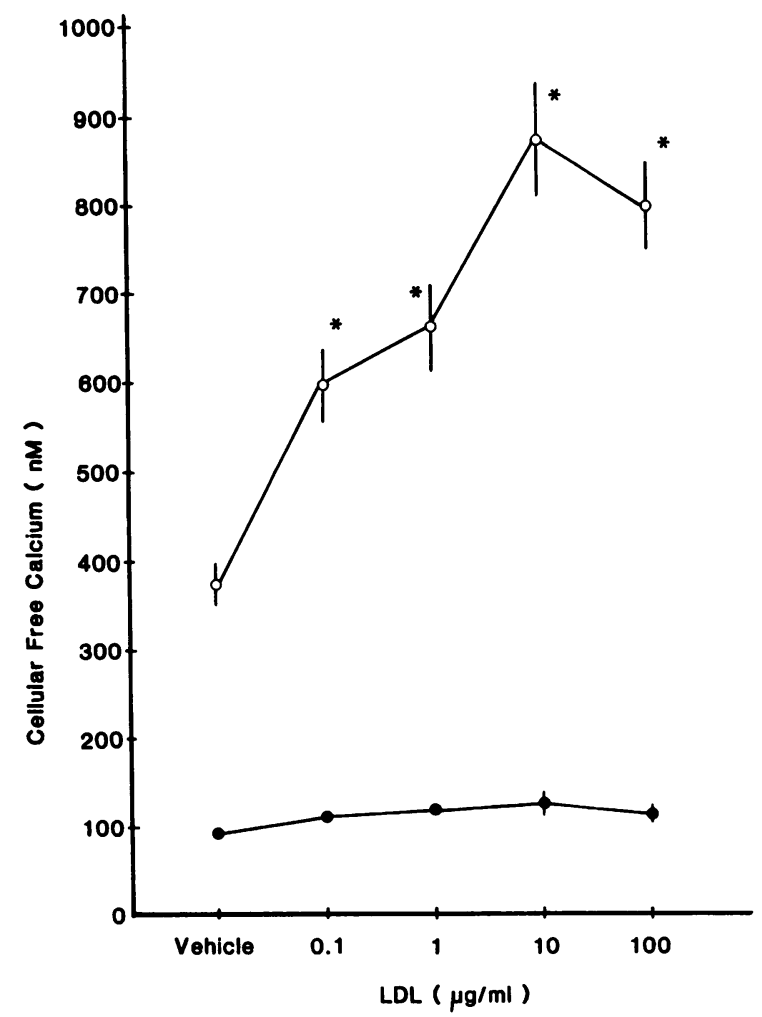

Figure 2. LDL accelerates the AVP-induced increase in $\left[\mathrm{Ca}^{2+}\right] \mathrm{i}$ in the cultured rat glomerular mesangial cells. The cells were preincubated for $24 \mathrm{~h}$ with the indicated concentration of LDL. (•) Basal $\left[\mathrm{Ca}^{2+}\right] \mathrm{i}$. (O) $1 \times 10^{-7} \mathrm{M}$ AVP-mobilized $\left[\mathrm{Ca}^{2+}\right]$ i. ${ }^{*} P<0.01$ vs. the vehicle. Values are means $\pm \mathrm{SEM}, n=5$.

increase in $\left[{ }^{3} \mathrm{H}\right]$ thymidine incorporation. The $\left[{ }^{3} \mathrm{H}\right]$ thymidine incorporation produced by AVP was significantly augmented by the simultaneous exposure of cells to 10 or $100 \mu \mathrm{g} / \mathrm{ml} \mathrm{LDL}$, since an incorporation was 1.5 - or 1.6 -fold greater than that in the absence of LDL. In contrast, LDL per se did not stimulate the $\left[{ }^{3} \mathrm{H}\right]$ thymidine incorporation into glomerular mesangial cells. We also examined the effect of the oxidized LDL on $\left[{ }^{3} \mathrm{H}\right]$ thymidine incorporation. The $1 \times 10^{-7} \mathrm{M}$ AVP-stimulated $\left[{ }^{3} \mathrm{H}\right]$ thymidine incorporation was $6.8 \times 10^{4} \mathrm{cpm} / \mathrm{mg}$ protein in the cells exposed to $10 \mu \mathrm{g} / \mathrm{ml}$ of the oxidized LDL, which was lower than that in the intact cells $(P<0.01)$.

Fig. 7 shows the activation of MAP kinase by AVP in the cultured rat glomerular mesangial cells. Basal activity of MAP kinase was $14.0 \pm 0.1 \mathrm{pmol} / \mathrm{mg}$ protein. AVP at a concentration of $1 \times 10^{-8} \mathrm{M}$ or higher activated MAP kinase in a dose-dependent manner (data not shown). $1 \times 10^{-7} \mathrm{M}$ AVP increased the activity of MAP kinase to $24.5 \pm 1.1 \mathrm{pmol} / \mathrm{mg}$ protein $(P$ $<0.01$ ). A $24 \mathrm{hr}$ exposure of cells to 10 or $100 \mu \mathrm{g} / \mathrm{ml} \mathrm{LDL}$ significantly accelerated the AVP-activated MAP kinase $(P$ $<0.05$ ). However, such a treatment with $10 \mu \mathrm{g} / \mathrm{ml}$ LDL or an acute exposure to $10 \mu \mathrm{g} / \mathrm{ml}$ LDL did not affect the basal activity of MAP kinase. In addition, the activation of MAP kinase by PMA was remarkably strong, as $1 \times 10^{-6} \mathrm{M}$ PMA activated MAP kinase to $57.2 \pm 1.9 \mathrm{pmol} / \mathrm{mg}$ protein $(P<0.01)$. The study was also carried out in cells pretreated for $24 \mathrm{~h}$ with 10 $\mu \mathrm{g} / \mathrm{ml}$ of the oxiaized LDL. MAP kinase was not activated by 1 $\times 10^{-7} \mathrm{M}$ AVP, as the activities of MAP kinase were $13.2 \pm 1.2$ and $14.4 \pm 0.7 \mathrm{pmol} / \mathrm{mg}$ protein in cells exposed to the vehicle and $1 \times 10^{-7} \mathrm{M} \mathrm{AVP}$, respectively.

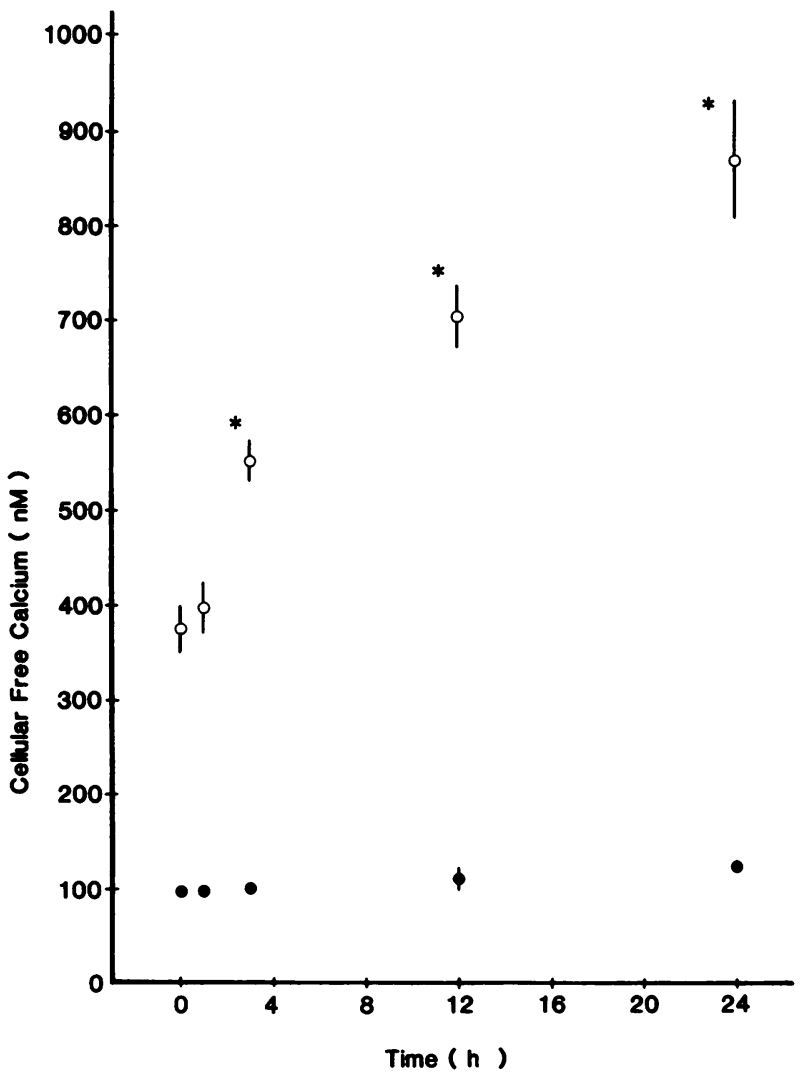

Figure 3. The enhancement by LDL of the AVP-induced $\left[\mathrm{Ca}^{2+}\right] \mathrm{i}$ in the cultured rat glomerular mesangial cells. The cells were preincubated with $10 \mu \mathrm{g} / \mathrm{ml} \mathrm{LDL}$ for the indicated time. (•) Basal $\left[\mathrm{Ca}^{2+}\right] \mathrm{i}$. (O) $1 \times 10^{-7} \mathrm{M}$ AVP-mobilized $\left[\mathrm{Ca}^{2+}\right]$ i. ${ }^{*} P<0.01$ vs. the group of cells that was not pretreated with LDL. Values are means \pm SEM, $n=5$.

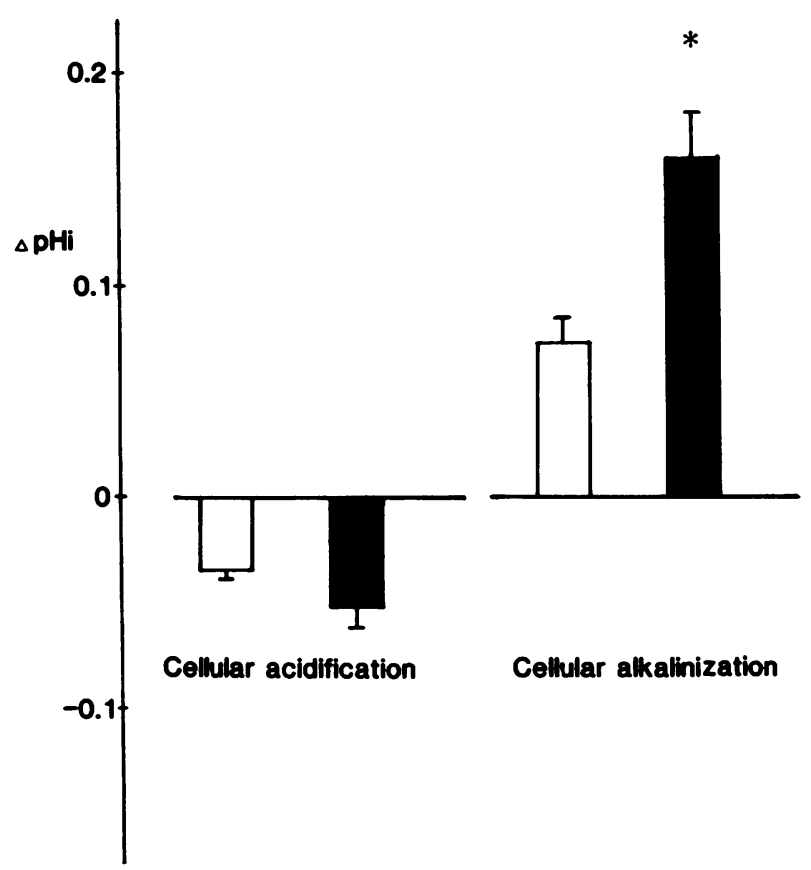

Figure 4. Effect of $10 \mu \mathrm{g} / \mathrm{ml} \mathrm{LDL}$ on $\mathrm{pHi}$ in response to $1 \times 10^{-7} \mathrm{M}$ AVP in the cultured rat glomerular mesangial cells. The graph shows the minimum and maximum pHi as $\Delta \mathrm{pHi}$. Open bars show the control group. Solid bars show the LDL group of cells, preincubated for $24 \mathrm{~h}$ with $10 \mu \mathrm{g} / \mathrm{ml} \mathrm{LDL} .{ }^{*} P<0.01$ vs. the control. Values are means \pm SEM, $n=5$. 


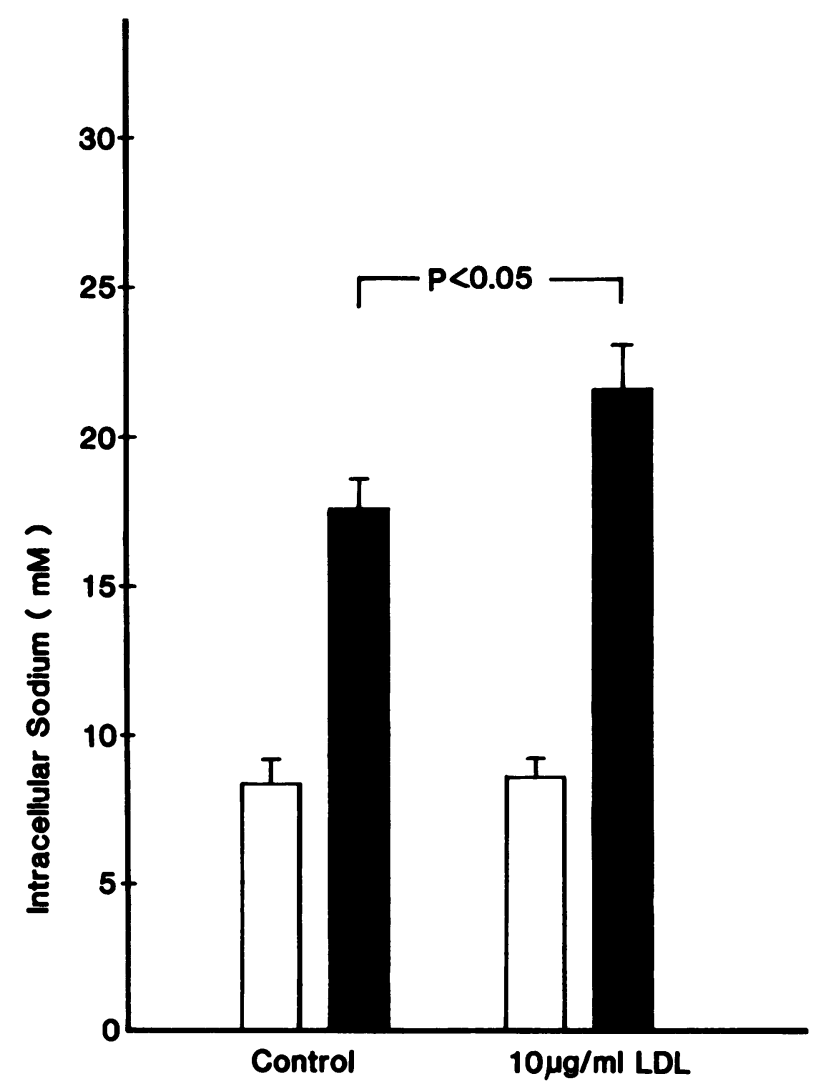

Figure 5. The augmentation by LDL of the AVP-induced increase in $\left[\mathrm{Na}^{+}\right] \mathrm{i}$ in the cultured rat glomerular mesangial cells. The cells were pretreated with $10 \mu \mathrm{g} / \mathrm{ml} \mathrm{LDL}$ or the vehicle for $24 \mathrm{~h}$. Open bars show the basal $\left[\mathrm{Na}^{+}\right] \mathrm{i}$, and solid bars show the $1 \times 10^{-7} \mathrm{M}$ AVP-induced $\left[\mathrm{Na}^{+}\right]$i. Values are means \pm SEM, $n=5$.

We examined the effect of LDL on $\left[{ }^{3} \mathrm{H}\right] \mathrm{AVP}$ binding to the cultured rat glomerular mesangial cells. Scatchard analysis shows in Fig. 8. $K_{\mathrm{d}}$ and $B_{\max }$ were $3.7 \times 10^{-9} \mathrm{M}$ and $7.3 \times 10^{-11}$ $\mathrm{M} / \mathrm{mg}$ protein in the intact cells, respectively. Also, $K_{\mathrm{d}}$ and $B_{\max }$ were $3.8 \times 10^{-9} \mathrm{M}$ and $7.6 \times 10^{-11} \mathrm{M} / \mathrm{mg}$ protein in the cells pretreated with $10 \mu \mathrm{g} / \mathrm{ml} \mathrm{LDL}$. There was no difference in $K_{\mathrm{d}}$ and $B_{\max }$ between the two groups of the cells pretreated with $10 \mu \mathrm{g} / \mathrm{ml} \mathrm{LDL}$ and the intact cells.

Whether LDL modulates the AVP-induced increase in $\mathrm{IP}_{3}$ production in the cultured rat glomerular mesangial cells was examined. As shown in Fig. 9, $1 \times 10^{-7} \mathrm{M}$ AVP caused a significant increase in $\mathrm{IP}_{3}$ production $(P<0.01)$. Such an AVP-induced increase in $\mathrm{IP}_{3}$ production was significantly enhanced by the $24-\mathrm{h}$ preexposure of cells to $10 \mu \mathrm{g} / \mathrm{ml} \mathrm{LDL}$. The pretreatment of cells with $10 \mu \mathrm{g} / \mathrm{ml} \mathrm{LDL}$ for $24 \mathrm{~h}$ did not affect the basal level of $\mathrm{IP}_{3}$ production.

Lastly, we examined the effect of $10 \mu \mathrm{g} / \mathrm{ml} \mathrm{LDL}$ on angiotensin II- and endothelin-1-induced increases in $\left[\mathrm{Ca}^{2+}\right] \mathrm{i}$ in the cultured rat glomerular mesangial cells. $1 \times 10^{-7} \mathrm{M}$ angiotensin II and endothelin-1 increased $\left[\mathrm{Ca}^{2+}\right] \mathrm{i}$ significantly (angiotensin II, from $95.2 \pm 3.9$ to $254.6 \pm 15.4 \mathrm{nM}$; and endothelin-1, from $88.2 \pm 2.6$ to $281.1 \pm 10.4 \mathrm{nM}, P<0.01$ ). When cells were exposed for $24 \mathrm{~h}$ to $10 \mu \mathrm{g} / \mathrm{ml} \mathrm{LDL}$, the angiotensin II- and endothelin-1-induced increases in $\left[\mathrm{Ca}^{2+}\right] \mathrm{i}$ were significantly accelerated, similar to the study with AVP $\left(1 \times 10^{-7} \mathrm{M}\right.$ angiotensin II, $254.6 \pm 15.4$ vs. $457.0 \pm 12.0 \mathrm{nM}, P<0.01$; and 1 $\times 10^{-7} \mathrm{M}$ endothelin-1, $281.1 \pm 10.4$ vs. $487.2 \pm 18.7 \mathrm{nM}, P$ $<0.01)$.

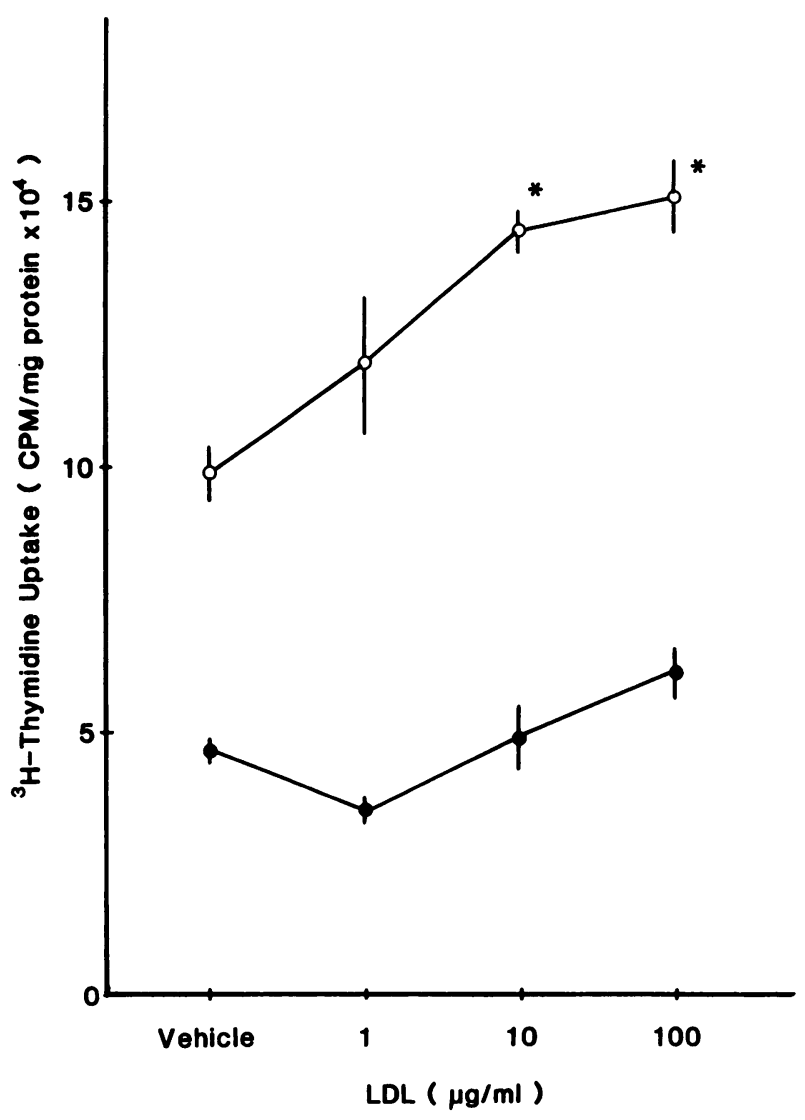

Figure 6. LDL accelerates the AVP-induced $\left[{ }^{3} \mathrm{H}\right]$ thymidine incorporation into the cultured rat glomerular mesangial cells. The cells were preincubated for $24 \mathrm{~h}$ with the indicated concentration of LDL. (•) Control. (O) $1 \times 10^{-7} \mathrm{M}$ AVP-induced $\left[{ }^{3} \mathrm{H}\right]$ thymidine incorporation. ${ }^{*} P<0.01$ vs. the vehicle. Values are means \pm SEM. Data were derived from four independent experiments, which included three observations in each experiment.

\section{Discussion}

It is well known that $\left[\mathrm{Ca}^{2+}\right] \mathrm{i}$ is the cellular second messenger for AVP in glomerular mesangial cells, in which mobilization is dependent on the breakdown of phosphatidylinositol $(3,4)$. The $V_{1}$ receptors are involved in the cellular action of AVP. The biological activity of AVP to mobilize $\left[\mathrm{Ca}^{2+}\right] \mathrm{i}$ is 100 times greater than that of angiotensin II (6). The early mobilization of $\left[\mathrm{Ca}^{2+}\right] \mathrm{i}$ is derived from both intra- and extra-cellular $\mathrm{Ca}^{2+}$, and the sustained phase depends to a great extent on extra-cellular $\mathrm{Ca}^{2+}$. Such a hormonally mobilized $\left[\mathrm{Ca}^{2+}\right] \mathrm{i}$ results in contraction of glomerular mesangial cells $(4,35)$. We further demonstrated that AVP increases $\left[\mathrm{Na}^{+}\right] \mathrm{i}$ and produces a biphasic change in pHi, i.e., an early cellular acidification followed by a sustained cellular alkalinization (6). The AVP-induced increase in $\left[\mathrm{Na}^{+}\right] \mathrm{i}$ depends on the cellular second messenger $\left[\mathrm{Ca}^{2+}\right] \mathrm{i}$ and the change in $\left[\mathrm{Na}^{+}\right] \mathrm{i}$ is closely related to that in $\mathrm{pHi}(6)$. Since cellular alkalinization enhances cell contraction, cellular growth, etc, in glomerular mesangial cells ( 2 , $5,36)$, it is of great value to elucidate the mechanisms for the interactions of $\left[\mathrm{Ca}^{2+}\right] \mathrm{i}, \mathrm{pHi}$ and $\left[\mathrm{Na}^{+}\right] \mathrm{i}$ in the cellular action of AVP.

The present study demonstrated that LDL enhances the cellular signal transduction of AVP in the cultured rat glomerular mesangial cells. The AVP-induced mobilization of $\left[\mathrm{Ca}^{2+}\right]$ - 


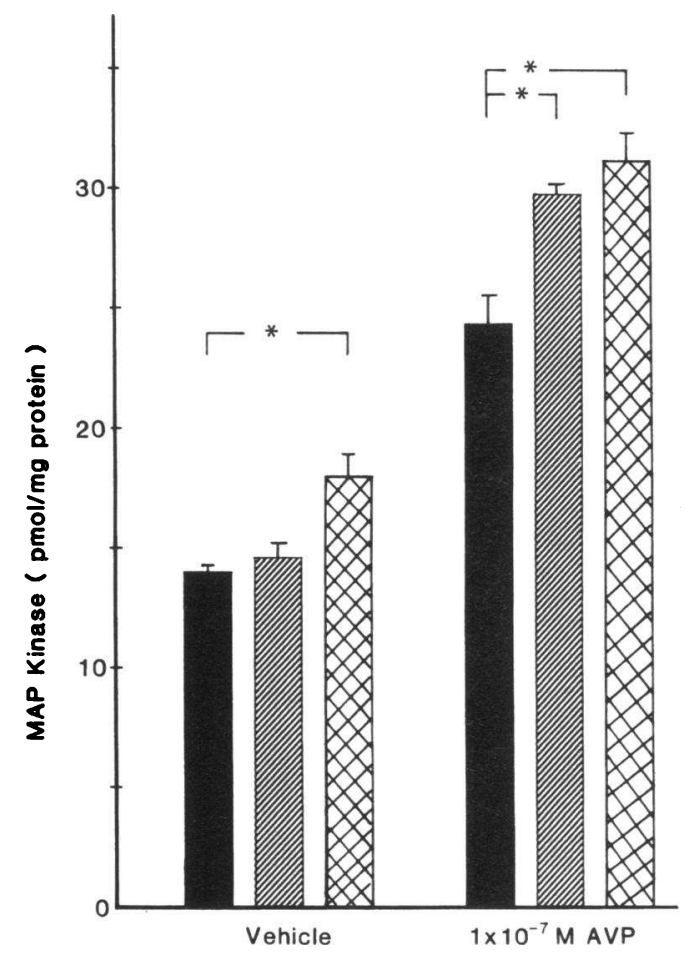

Figure 7. Effect of LDL on the AVP-activated MAP kinase in the cultured rat glomerular mesangial cells. Solid bars show the control group. Hatched and cross-hatched bars show the LDL group of cells, pretreated for $24 \mathrm{~h}$ with 10 and $100 \mu \mathrm{g} / \mathrm{ml} \mathrm{LDL}$, respectively. ${ }^{*} P<0.05$. Values are means $\pm \mathrm{SEM}, n=6$.

$i$ and $\left[\mathrm{Na}^{+}\right]$i and cellular alkalinization were markedly accelerated by the pretreatment of cells with LDL. Such an acceleration was obtained with $>0.1 \mu \mathrm{g} / \mathrm{ml} \mathrm{LDL}$ and the preincubation of $>3 \mathrm{~h}$. LDL did not affect the $\left[{ }^{3} \mathrm{H}\right]$ AVP receptor binding, but significantly increased the AVP-induced

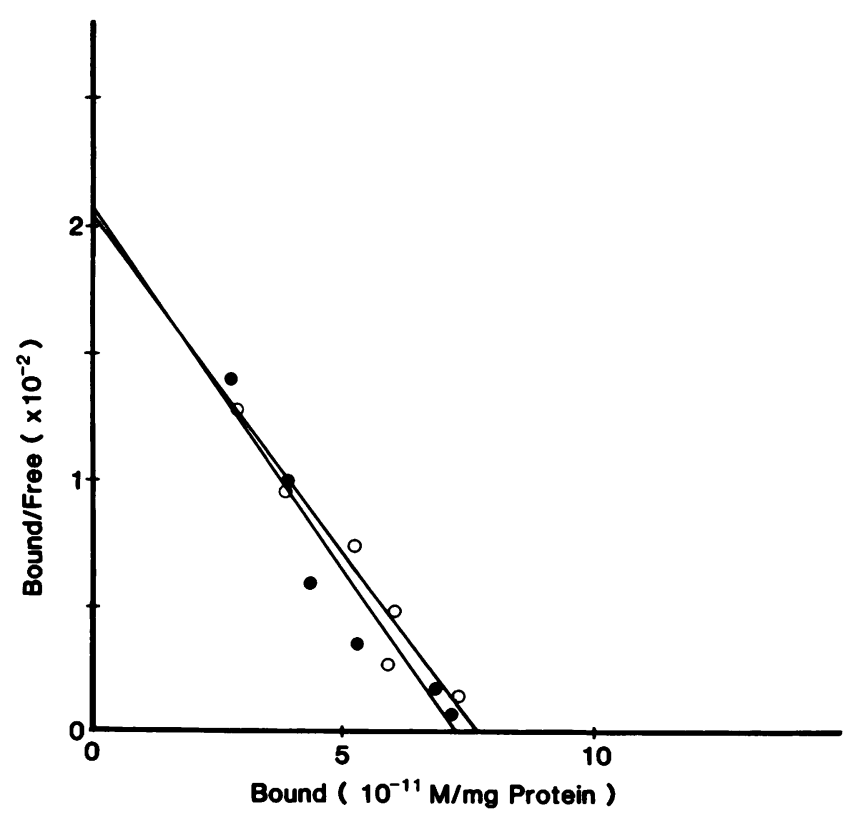

Figure 8. Scatchard analysis of $\left[{ }^{3} \mathrm{H}\right]$ AVP binding to the cultured rat glomerular mesangial cells. (•) Control group. (O) Group of cells pretreated with $10 \mu \mathrm{g} / \mathrm{ml} \mathrm{LDL}$ for $24 \mathrm{~h}$.

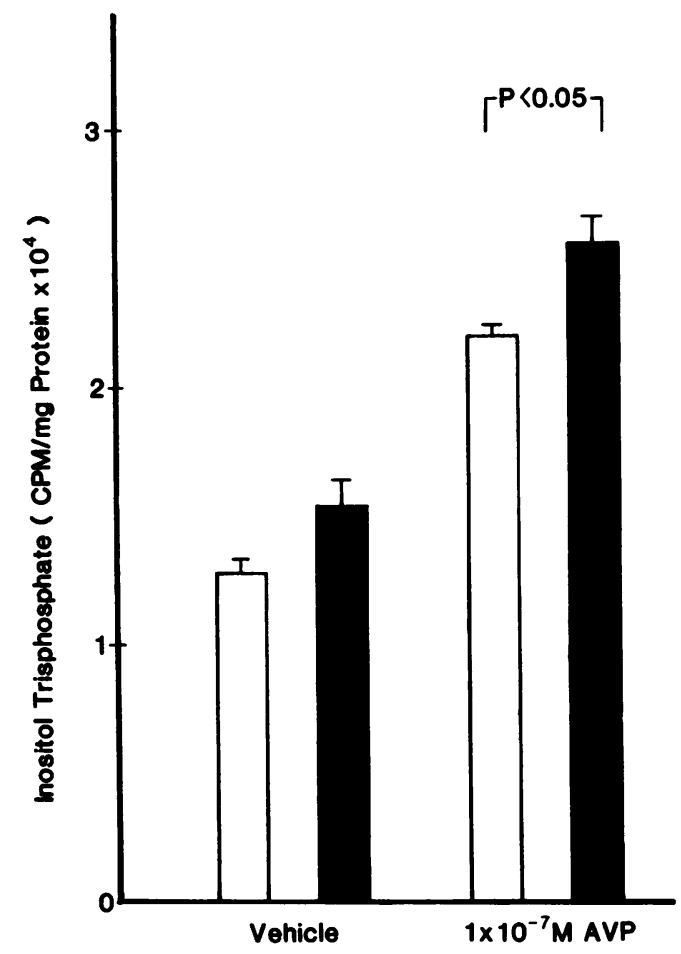

Figure 9. The enhancement by LDL of the AVP-induced increase in $\mathrm{IP}_{3}$ production in the cultured rat glomerular mesangial cells. Open bars show the control group. Solid bars show the group of cells pretreated with $10 \mu \mathrm{g} / \mathrm{ml} \mathrm{LDL}$ for $24 \mathrm{~h}$. Values are means \pm SEM. Data were derived from three independent experiments, which included three observations in each experiment.

increase in $\mathrm{IP}_{3}$ production. Thus, the site of action is the hydrolysis of phosphatidylinositol. In contrast, the 24-h exposure of cells to LDL did not affect the basal levels of $\mathrm{IP}_{3}$ and $\left[\mathrm{Ca}^{2+}\right]$. Also, an acute administration of LDL did not alter $\left[\mathrm{Ca}^{2+}\right] \mathrm{i}$ in glomerular mesangial cells. The present results therefore indicate that LDL augments the vasoconstrictor hormone AVP-induced cellular signal transduction in the cultured rat glomerular mesangial cells, but LDL itself does not stimulate phosphatidylinositol hydrolysis or the mobilization of $\left[\mathrm{Ca}^{2+}\right] \mathrm{i}$. The acceleration by LDL of vasoconstrictor hormone-induced $\left[\mathrm{Ca}^{2+}\right]$ i mobilization was also found with angiotensin II and endothelin-1. Similar results were obtained in endothelial cells and vascular smooth muscle cells $(20,37)$. In those studies, LDL stimulates cellular proliferation in the presence of low concentration of epidermal growth factor. In other studies, in contrast, LDL per se stimulates phospholipase C-mediated hydrolysis of phosphatidylinositol bisphosphate and causes a transient rise in $\left[\mathrm{Ca}^{2+}\right] \mathrm{i}$ in platelets, fibroblasts, and vascular smooth muscle cells $(17,20,21,38,39)$.

AVP stimulated $\left[{ }^{3} \mathrm{H}\right]$ thymidine incorporation into the cultured rat glomerular mesangial cells. The AVP-induced $\left[{ }^{3} \mathrm{H}\right]-$ thymidine incorporation was totally blocked by the presence of $1 \times 10^{-6} \mathrm{M}$ the nonpeptide $\mathrm{V}_{1}$ AVP antagonist, $1-\{1$ [4-(3-acetylaminopropoxyl)]-4-piperidyl \}-3,4-dihydro-2(1H)-quinolinone (OPC-21268) (40) (unpublished observation). AVP regulates cellular DNA replication of mesangial cells mediated via the $V_{1}$ receptors. Such a vasoconstrictor hormone-stimulated DNA replication has been obtained with AVP and angiotensin II in homologous cells of vascular smooth muscle cells $(12,41)$. Also, we showed that AVP and PMA activate the 
MAP kinase in glomerular mesangial cells. MAP kinase is serine/threonine-specific protein kinase and is downstream of protein kinase $\mathrm{C}$ in the signal transduction pathway of AVP. MAP kinase causes an increase in the phosphorylation of cmyc and c-fos in the nucleus (16). Therefore, MAP kinase is known to be a valuable index of cellular growth stimulated by vasoactive hormones. The present study further demonstrated that LDL enhanced the AVP-stimulated $\left[{ }^{3} \mathrm{H}\right]$ thymidine incorporation and MAP kinase activation in glomerular mesangial cells. Since the cellular proliferative effect of AVP is mediated through the $V_{1}$ receptors and phosphatidylinositol system, the action of LDL is probably based on the enhancement of phosphatidylinositol metabolism produced by AVP, as mentioned earlier. Also, we found the direct effect of LDL on cellular proliferation of mesangial cells, as the high dose of LDL as 100 $\mu \mathrm{g} / \mathrm{ml}$ activated MAP kinase. However, the lower dose of LDL did not directly cause cellular proliferation. The previous studies have shown that LDL directly stimulates cellular growth in several kinds of cells $(20,21)$. These results may be derived from the dose of LDL and the preincubation time. Chen et al. (20) used $20-60 \mu \mathrm{g} / \mathrm{ml} \mathrm{LDL}$ for $6 \mathrm{~d}$ to evaluate cellular growth of arterial endothelial and vascular smooth muscle cells.

We studied the effect of oxidized LDL on AVP-induced $\left[\mathrm{Ca}^{2+}\right] \mathrm{i}$ mobilization and cellular proliferation in glomerular mesangial cells. Exposure of cells to the oxidized LDL markedly reduced the AVP-induced $\left[\mathrm{Ca}^{2+}\right] \mathrm{i}$ mobilization, $\left[{ }^{3} \mathrm{H}\right]-$ thymidine incorporation and MAP kinase activation, as compared to LDL. Similar results were reported by Keane et al. (42), showing that native LDL subjected to chemical oxidation by copper sulfate inhibited mesangial cell proliferation. Therefore, the accelerative effect of LDL on the action of AVP is distinct from the effect of oxidized LDL.

In summary, the present study demonstrated that LDL enhances the cellular signal transduction of AVP in glomerular mesangial cells. The AVP-induced $\left[\mathrm{Ca}^{2+}\right] \mathrm{i}$ and $\left[\mathrm{Na}^{+}\right] \mathrm{i}$ mobilization and cellular alkalinization are significantly accelerated by the LDL pretreatment, mediated through an increase in the hydrolysis of phosphatidylinositol. This augmentation may closely relate to an increase in cellular contraction of glomerular mesangial cells in response to AVP. Also, such an effect on cellular proliferation is obtained, since LDL significantly enhances the AVP-induced $\left[{ }^{3} \mathrm{H}\right]$ thymidine incorporation and MAP kinase activation in glomerular mesangial cells. Its growth-stimulatory property is relevant to the accelerated growth of mesangial cells observed in glomerular disease associated with hypertension or athelosclerosis. These results indicate that LDL enhances the cellular action of AVP and the AVP-stimulated cellular proliferation in glomerular mesangial cells. A site of action of LDL is the breakdown of phosphatidylinositol.

\section{Acknowledgments}

This study was supported by a grant from the Ministry of Education, Science and Culture of Japan.

\section{References}

1. Ausiello, D. A., J. I. Kreisberg, C. Roy, and M. J. Karnovsky. 1980. Contraction of cultured rat glomerular cells of apparent mesangial origin after stimulation with angiotensin II and arginine vasopressin. J. Clin. Invest. 65:754-760.

2. Mene, P., M. S. Simonson, and M. J. Dunn. 1989. Physiology of the mesangial cells. Physiol. Rev. 69:1347-1424.
3. Bonventre, J. V., K. L. Skorecki, J. I. Kreisberg, and J. Y. Cheung. 1986. Vasopressin increases cytosolic free calcium concentration in glomerular mesangial cells. Am. J. Physiol. 251:F94-F102.

4. Takeda, K., H. Meyer-Lehnert, J. K. Kim, and R. W. Schrier. 1988. AVPinduced $\mathrm{Ca}^{2+}$ fluxes and contraction of rat glomerular mesangial cells. Am. J. Physiol. 255:F142-F150.

5. Ganz, M. B., M. C. Perfetto, and W. F. Boron. 1990. Effects of mitogens and other agents on rat mesangial cell proliferation, $\mathrm{pH}$ and $\mathrm{Ca}^{2+} . \mathrm{Am}$. J. Physiol. 259:F269-F278.

6. Ishikawa, S., K. Okada, and T. Saito. 1992. Increases in cellular sodium concentration by arginine vasopressin and endothelin in cultured rat glomerular mesangial cells. Endocrinology. 131:1429-1435.

7. Capponi, A. M., P. D. Lew, and M. B. Vallotton. 1985. Cytosolic free calcium levels in monolayers of cultured rat aortic smooth muscle cells. J. Biol. Chem. 260:7836-7842.

8. Bova, S., W. F. Goldman, X. J. Y. Yuan, and M. P. Blaustein. 1990 Influence of $\mathrm{Na}^{+}$gradient on $\mathrm{Ca}^{2+}$ transients and contraction in vascular smooth muscle. Am. J. Physiol. 259:H409-H423.

9. Okada, K., P. Tsai, V. A. Briner, C. Caramelo, and R. W. Schrier. 1991. Effects of extra- and intracellular $\mathrm{pH}$ on vascular action of arginine vasopressin. Am. J. Physiol. 260:F39-F45.

10. Okada, K., S. Ishikawa, and T. Saito. 1991. Mechanisms of vasopressininduced increase in intracellular $\mathrm{Na}^{+}$in vascular smooth muscle cells. Am. J. Physiol. 261:F1007-F1012.

11. Granot, Y., E. Erikson, H. Fridman, V. Van Putten, B. Williams, R. W. Schrier, and J. L. Maller. 1993. Direct evidence for tyrosine and threonine phosphorylation and activation of mitogen-activated protein kinase by vasopressin in cultured rat vascular smooth muscle cells. J. Biol. Chem. 268:9564-9569.

12. Nambi, P., R. Watt, M. Whitman, N. Aiyar, J. P. Moore, G. I. Evan, and S. Crooke. 1989. Induction of c-fos protein by activation of vasopressin receptors in smooth muscle cells. FEBS (Fed. Eur. Biochem. Soc.) Lett. 245:61-64.

13. Granot, Y., V. Van Putten, and R. W. Schrier. 1990. Vasopressin dependent tyrosine phosphorylation of a $38 \mathrm{kDa}$ protein in human platelets. Biochem. Biophys. Res. Commun. 168:566-573.

14. Force, T., J. M. Kyriakis, J. Avruch, and J. V. Bonventre. 1991. Endothelin, vasopressin and angiotensin II enhance tyrosine phosphorylation by protein kinase C-dependent and -independent pathways in glomerular mesangial cells. $J$. Biol. Chem. 266:6650-6656.

15. Zachary, I., J. Gil, W. Lehmann, J. Sinnett-Smith, and E. Rozengurt 1991. Bombesin, vasopressin and endothelin rapidly stimulate tyrosine phosphorylation in intact Swiss 3T3 cells. Proc. Natl. Acad. Sci. USA. 88:4577-4581.

16. Davis, R. J. 1993. The mitogen-activated protein kinase signal transduction pathway. J. Biol. Chem. 268:14553-14556.

17. Buhler, F. R., V. A. Tkachuk, A. W. A. Hahn, and T. J. Resink. 1991. Low- and high-density lipoproteins as hormonal regulators of platelet, vascular endothelial and smooth muscle cell interactions: relevance to hypertension. $J$. Hypertens. 9:S28-S36.

18. Castelli, W. P., and K. Anderson. 1986. A population at risk: prevalence of high cholesterol levels in hypertensive patients in the Flamingham study. Am. J. Med. 80:23-32.

19. Ferranini, E., S. M. Haffner, and M. P. Stern. 1990. Essential hypertension: an insulin-resistant state. J. Cardiovasc. Pharmacol. 15:S18-S25.

20. Chen, J. K., H. Hoshi, D. B. McClure, and W. L. McKeenan. 1986. Role of lipoproteins in growth of human adult arterial endothelial and smooth muscle cells in low lipoprotein-deficient serum. J. Cell. Physiol. 129:207-214.

21. Scott-Burden, T., T. J. Resink, A. W. A. Hahn, U. Baur, R. J. Box, and F. R. Buhler. 1989. Induction of growth-related metabolism in human vascular smooth muscle cells by low density lipoprotein. J. Biol. Chem. 264:1258212589 .

22. Rayner, H. C., T. Horsburgh, S. L. Brown, F. L. Lavender, A. F. Winder, and J. Walls. 1990. Receptor-mediated endocytosis of low-density lipoprotein by cultured human glomerular cells. Nephron. 55:292-299.

23. Takemura, T., Y. Yoshida, N. Aya, K. Murakami, A. Matsumoto, H Itakura, T. Kodama, H. Suzuki, and S. Maki. 1993. Apolipoproteins and lipoprotein receptors in glomeruli in human kidney diseases. Kidney Int. 43:918-927.

24. Kreisberg, J. I., and M. J. Karnovsky. 1983. Glomerular cells in culture. Kidney Int. 23:439-447.

25. Ishikawa, S., K. Okada, and T. Saito. 1988. Arginine vasopressin increases cellular free calcium concentration and adenosine 3',5'-monophosphate production in rat renal papillary collecting tubule cells in culture. Endocrinology. 123:1376-1384.

26. Ishikawa, S., and T. Saito. 1990. Optimal concentration of cellular free calcium for AVP-induced cAMP in collecting tubules. Kidney Int. 37:1060-1066.

27. Magil, A. B., J. J. Frohlich, S. M. Innis, and U. P. Steinbrecher. 1993. Oxidized low-density lipoprotein in experimental focal glomerulosclerosis. Kidney Int. 43:1243-1250.

28. Grynkiewicz, C., M. Poenie, and R. Y. Tsien. 1985. A new generation of $\mathrm{Ca}^{2+}$ indicators with greatly improved fluorescence properties. J. Biol. Chem. 260:3440-3450.

29. Ishikawa, S., K. Okada, and T. Saito. 1990. Prompt inhibition of arginine 
vasopressin-induced cellular adenosine $3^{\prime}, 5^{\prime}$-monophosphate production by extracellular sodium depletion in rat renal inner medullary collecting duct cells in culture. Endocrinology. 127:560-566.

30. Ishikawa, S., K. Okada, and T. Saito. 1992. pH Dependence of the action of arginine vasopressin in renal collecting tubule. Am. J. Physiol. 262:F784F792.

31. Lowry, O. H., N. J. Rosebrough, A. L. Farr, and R. J. Randall. 1951. Protein measurement with the Folin phenol reagent. J. Biol. Chem. 193:265275.

32. Shirakabe, K., Y. Gotoh, and E. Nishida. 1992. A mitogen-activated protein (MAP) kinase activating factor in mammalian mitogen-stimulated cells is homologous to Xenopus $\mathrm{M}$ phase MAP kinase activator. J. Biol. Chem. 267:16685-16690.

33. Fishman, J. B., B. F. Dickey, N. L. Bucher, and R. E. Fine. 1985. Internalization, recycling and redistribution of vasopressin receptors in rat hepatocytes. $J$. Biol. Chem. 260:12641-12646.

34. Okada, K., C. Caramelo, P. Tsai, and R. W. Schrier. 1990. Effect of inhibition of $\mathrm{Na}^{+} / \mathrm{K}^{+}$-adenosine trisphosphatase on vascular action of vasopressin. J. Clin. Invest. 86:1241-1248.

35. Meyer-Lehnert, H., and R. W. Schrier. 1988. Cyclosporine A enhances vasopressin-induced $\mathrm{Ca}^{2+}$ mobilization and contraction in mesangial cells. Kidney Int. 34:89-97.

36. Ganz, M. B., S. K. Pekar, M. C. Perfetto, and R. B. Sterzel. 1988. Arginine vasopressin promotes growth of rat glomerular mesangial cells in culture. Am.J. Physiol. 255:F898-F906.

37. Galle, J., E. Bassenger, and R. Busse. 1990. Oxidized low density lipoprotein potentiates vasoconstriction to various agonists by direct interaction with vascular smooth muscle. Circ. Res. 86:75-79.

38. Block, L. H., M. Knorr, E. Vogt, R. Locher, W. Vetter, P. Groscurth, B. Y. Qiao, D. Pometta, P. James, M. Regenass, et al. 1988. Low density lipoprotein causes general cellular activation with increased phosphatidylinositol turnover and lipoprotein catabolism. Proc. Natl. Acad. Sci. USA. 85:885-889.

39. Sachinidis, A., T. Mengden, R. Locher, C. Brunner and W. Vetter. 1990. Novel cellular activities for low density lipoprotein in vascular smooth muscle cells. Hypertension. 15:704-711.

40. Yamamura, Y., H. Ogawa, T. Chihara, K. Kondo, T. Onogawa, S. Nakamura, T. Mori, M. Tominaga, and Y. Yabuuchi. 1991. OPC-21268, an orally effective, non-peptide vasopressin $\mathrm{V}_{1}$ receptor antagonist. Science (Wash. DC). 252:572-574.

41. Taubman, M. B., B. C. Berk, S. Izumo, T. Tsuda, R. W. Alexander, and B. Nadal-Ginard. 1989. Angiotensin II induces c-fos mRNA in aortic smooth muscle. J. Biol. Chem. 264:526-530.

42. Keane, W. F., M. P. O'Donnell, B. L. Kaiske, and Y. Kim. 1993. Oxidative modification of low-density lipoproteins by mesangial cells. J. Am. Soc. Nephrol. 4:187-194. 